\title{
Design of a novel calcium sulfate-based lightweight composite: towards excellent thermal properties
}

\section{Citation for published version (APA):}

Yu, Q., \& Brouwers, H. J. H. (2013). Design of a novel calcium sulfate-based lightweight composite: towards excellent thermal properties. Advanced Materials Research, 651, 745-750.

https://doi.org/10.4028/www.scientific.net/AMR.651.745

DOI:

10.4028/www.scientific.net/AMR.651.745

Document status and date:

Published: 01/01/2013

\section{Document Version:}

Publisher's PDF, also known as Version of Record (includes final page, issue and volume numbers)

\section{Please check the document version of this publication:}

- A submitted manuscript is the version of the article upon submission and before peer-review. There can be important differences between the submitted version and the official published version of record. People interested in the research are advised to contact the author for the final version of the publication, or visit the $\mathrm{DOI}$ to the publisher's website.

- The final author version and the galley proof are versions of the publication after peer review.

- The final published version features the final layout of the paper including the volume, issue and page numbers.

Link to publication

\section{General rights}

Copyright and moral rights for the publications made accessible in the public portal are retained by the authors and/or other copyright owners and it is a condition of accessing publications that users recognise and abide by the legal requirements associated with these rights.

- Users may download and print one copy of any publication from the public portal for the purpose of private study or research.

- You may not further distribute the material or use it for any profit-making activity or commercial gain

- You may freely distribute the URL identifying the publication in the public portal.

If the publication is distributed under the terms of Article 25fa of the Dutch Copyright Act, indicated by the "Taverne" license above, please follow below link for the End User Agreement:

www.tue.nl/taverne

Take down policy

If you believe that this document breaches copyright please contact us at:

openaccess@tue.nl

providing details and we will investigate your claim. 


\title{
Design of a Novel Calcium Sulfate-Based Lightweight Composite: Towards Excellent Thermal Properties
}

\author{
Q.L. Yu ${ }^{1, a}$ and H.J.H. Brouwers ${ }^{1, b}$ \\ ${ }^{1}$ Department of the Built Environment, Eindhoven University of Technology, P. O. Box 513, 5600 MB \\ Eindhoven, the Netherlands \\ aq.yu@bwk.tue.nl, bjos.brouwers@tue.nl
}

Keywords: calcium sulfate; lightweight composite; thermal physical properties, fire behavior.

\begin{abstract}
This article addresses the design of a self-compacting gypsum-based lightweight composite (SGLC). A $\beta$-hemihydrate is used as binder and lightweight aggregate (LWA, 0-2 $\mathrm{mm}$ in different size ranges) is used as aggregate into this composite. The mix of the new composite is designed based on the particle size distribution grading theory applying the modified Andreasen and Andersen (A\&A) grading line to obtain an optimal packing of all the used solid materials. The thermal behavior of the new developed composite is investigated, from its thermal physical properties and fire behavior. The study demonstrates that this new composite has significant improvement compared to those of traditional gypsum plasterboard.
\end{abstract}

\section{Introduction}

Gypsum plaster is one of the earliest building materials elaborated by mankind and its utilization history can be traced to 4000 years ago. As an excellent environmentally friendly and sustainable building material, gypsum is used extensively for interior walls or ceilings due to its easy fabrication features, environmental friendliness, aesthetics, low price etc., and also especially due to its very good fire resistance property.

The present research aims at the development of an environmentally friendly $\mathrm{CaSO}_{4} \cdot \mathrm{H}_{2} \mathrm{O}$-based lightweight composite with a further improved fire resistance, sufficient strength, and indoor air quality improvement properties. To obtain a low thermal conductivity, a regenerated lightweight material is used into this new composite as lightweight aggregate. The particles of the lightweight material are rather closed hollow spheres, assuring a low density and a good thermal insulation. A $\beta$-hemihydrate $\left(\mathrm{CaSO}_{4} \cdot 0.5 \mathrm{H}_{2} \mathrm{O}\right)$ produced from flue gas desulfurization (FGD) gypsum is used here as binder. The mix of the new composite was designed based on the packing theory applying the modified Andreasen and Andersen (A\&A) grading model [1] to achieve an optimal packing of all the applied solid materials, in order to obtain a relatively high mechanical properies of the mixes. The thermal physical properties such as thermal conductivity, and the fire behavior of the developed composite is investigated and discussed in the present article.

\section{Mix design}

The mixes were designed in the present study applying a model, so called modified Andreasen and Andersen Equation

$$
P(D)=\frac{D^{q}-D_{\min }^{q}}{D_{\max }^{q}-D_{\text {min }}^{q}}
$$

where $P(D)$ is a fraction of the total solids being smaller than size $D, D_{\max }$ is the maximum particle size $(\mu \mathrm{m}), D_{\min }$ is the minimum particle size $(\mu \mathrm{m})$ and $\mathrm{q}$ is distribution modulus.

Applying the PSD theory, the particles can be better packed, which results in an improved hardened state properties as well as an improved workability, since more water is available to act as the lubricant between the particles [2]. In this mix design method, the modified Andreasen and Andersen 
curve acts as a target function for the optimization of the individual granular materials. The proportions of the individual materials in the mix design are adjusted until an optimum fit is reached between the composed mix and the target value, using an optimization algorithm as so called Least Squares Method (LSM), i.e. the deviation between target curve and composed mix expressed by the sum of the squares of the residuals (RSS) at defined particle sizes [3], as shown in Fig. 1. This is reached by employing the Solver tool in Microsoft Excel ${ }^{\circledR}$.

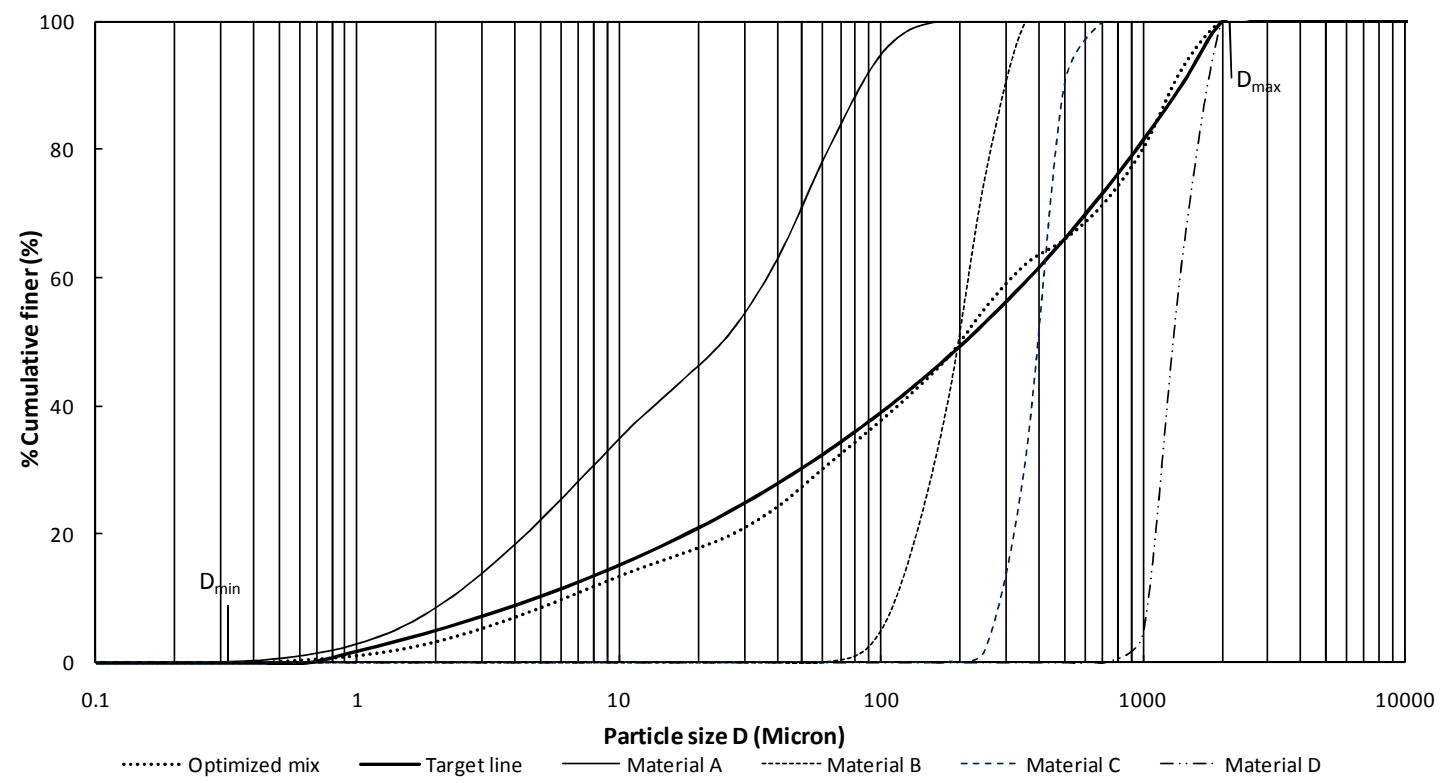

Fig. 1: PSDs of the involved ingredients, the target line and the resulting integral grading line of the mix.

Following the optimization of the solid ingredients, the water content, or here the water dosage based on the amount of $\beta$-hemihydrate (water/hemihydrate by mass) is determined. To ensure the mixed system is fluid, a thin layer of adsorbed water molecules around the particles and an extra amount of water to fill the intergranular voids of the system are necessary. The water content is strongly linked to both the flowability of the mixture in its fresh state, and the strength of the mixture in its hardened state [4]. The water content here was determined applying the mini-slump flow test, using a Hägermann cone, a detailed analysis is presented in [4].

Table 1: Compositions of four mixes designed applying this mix design concept (per $1 \mathrm{~m}^{3}$ ).

\begin{tabular}{ccccc}
\hline Material & Mix 1 & Mix 2 & Mix 3 & Mix 4 \\
\hline B-hemihydrate & 687.0 & 593.8 & 532.6 & 474.0 \\
LWA 0.1-0.3 & 67.9 & 102.9 & 97.5 & 94.8 \\
LWA 0.25-0.5 & 16.9 & 15.8 & 52.5 & 42.1 \\
LWA 0.5-1.0 & 59.4 & 39.6 & 26.3 & 35.1 \\
LWA 1.0-2.0 & 17.0 & 39.6 & 41.3 & 56.2 \\
Water & 412.2 & 385.9 & 372.8 & 355.5 \\
SP (\%) & $0.20 \%$ & $0.25 \%$ & $0.30 \%$ & $0.30 \%$ \\
\hline
\end{tabular}

With the determined water demand, the preliminary mix design, i.e. the determination of solid materials and water content, is completed. However, it should be noted that with this water content the slump flow of the mixture is zero. The next step is to adjust the flowability until a desired design target. According to the standard EN 13454-2 [5], a flowable mortar and a highly plastic mortar based 
on gypsum should have a slump flow no less than $190 \mathrm{~mm}$ and $130 \mathrm{~mm}$, respectively, while from EFNARC [6], the slump flow of cement mortar should be between 240-260 mm. Here using EFNARC [6] as a reference, the slump flow value is set as $220-250 \mathrm{~mm}$. The flowability was modified by dosing a specially designed superplasticizer (SP) by Sika and slightly modifying water dosage if necessary. With the new designed composite, experimental results show that the required flowability can be reached only by adding the SP without changing the water content, as shown in Table 1.

\section{Thermal physical properties}

As one of the key topics in building research, fire resistance is always receiving special attention due to the very important role it plays in the safety of human beings. To prevent the premature collapse when heated, the main building structures should have good fire separations. To ensure an excellent fire resistance of a building structure, good thermo physical properties such as a low thermal conductivity are very important to be obtained. On the other hand, a low thermal conductivity of the applied building structure also contributes to a good thermal comfort, due to the low heat transfer through it between the indoor and outdoor conditions.

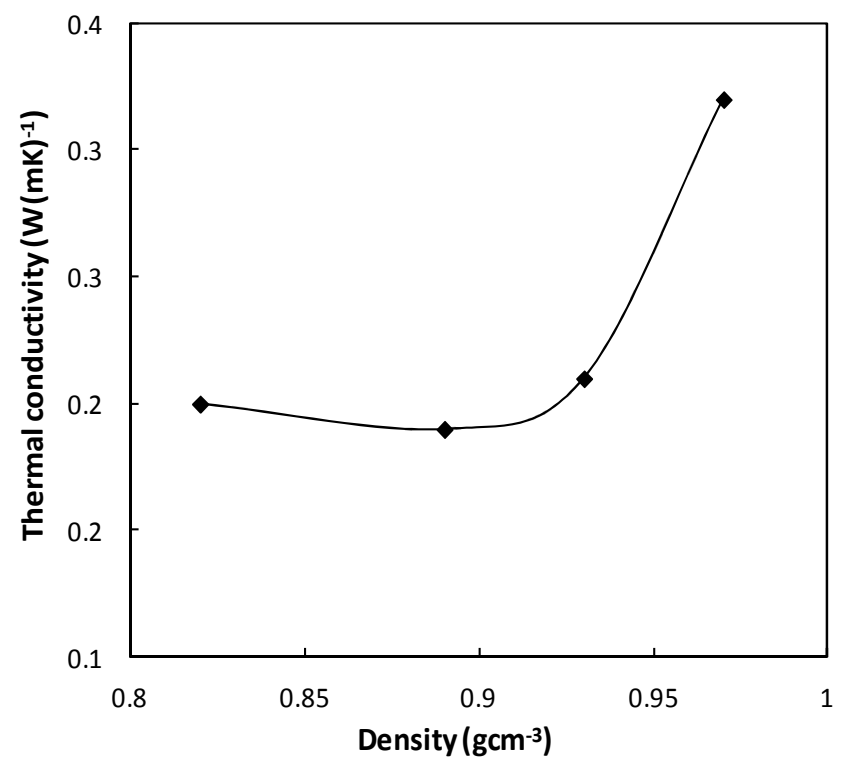

Fig. 2: Thermal conductivity of the designed composies versus the densities.

The measured thermal conductivities of the new composite versus the densities are shown in Fig. 2. It is shown that the thermal conductivity remains stable at a lower density and then increases quickly with the increase of the density. This is in line with De Korte and Brouwers [7] and Zehner and Schlunder [8], who reported that the thermal conductivity is related not only with the density, but also strongly with the composition. It should also be pointed out that, to reach a lower thermal conductivity, it is not enough only to consider the reduction of the density. Here, a thermal conductivity of $0.21 \mathrm{~W} /(\mathrm{m} \cdot \mathrm{K})$ is obtained at a void fraction of 0.60 (with the density of $0.93 \mathrm{~g} / \mathrm{cm}^{3}$ ), while in the previous study a thermal conductivity of $0.30 \mathrm{~W} /(\mathrm{m} \cdot \mathrm{K})$ is obtained at the same void fraction for pure gypsum board [9]. Hence, it can be concluded that a $30 \%$ improvement of the thermal conductivity is reached with the SGLC.

\section{Fire behavior}

The fire behavior of the developed SGLC was investigated by performing the real fire test on the designed samples. The furnace employed in this study was developed by AIDICO in Spain [10], as shown in Fig. 3a. The furnace was built vertically with a surface of exposure of $9 \mathrm{~m}^{2}$ according to 
standard EN 1363-1:1999 and EN 1363-2:1999. The wall of the furnace is made of bricks and coated with refractory cement mortar. Along the wall 7 burners (14 burners in both left and right sides) are assembled vertically, and the burners are $38 \mathrm{~cm}$ away from the wall, as shown in Fig. $3 \mathrm{~b}$.

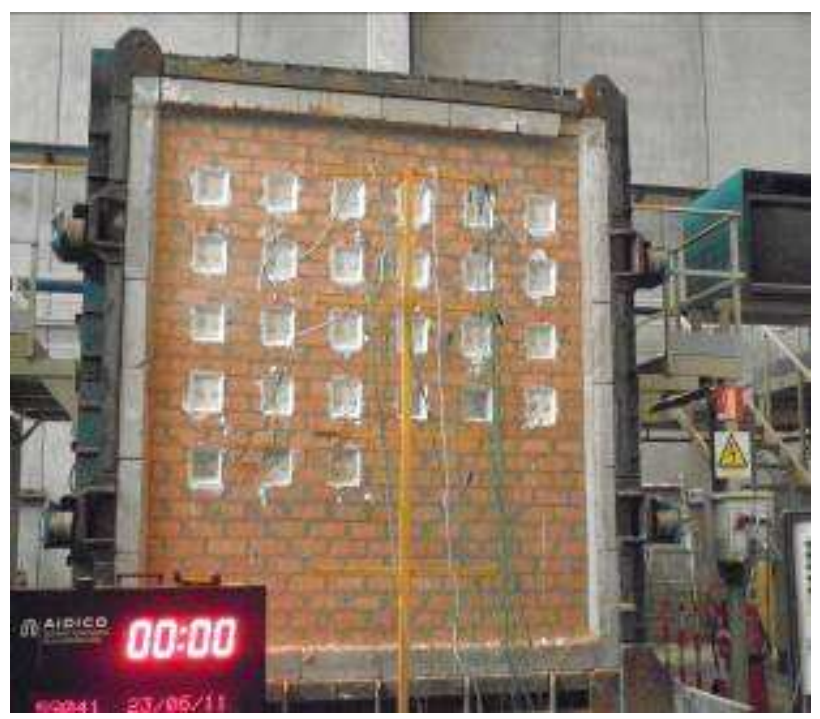

(a)

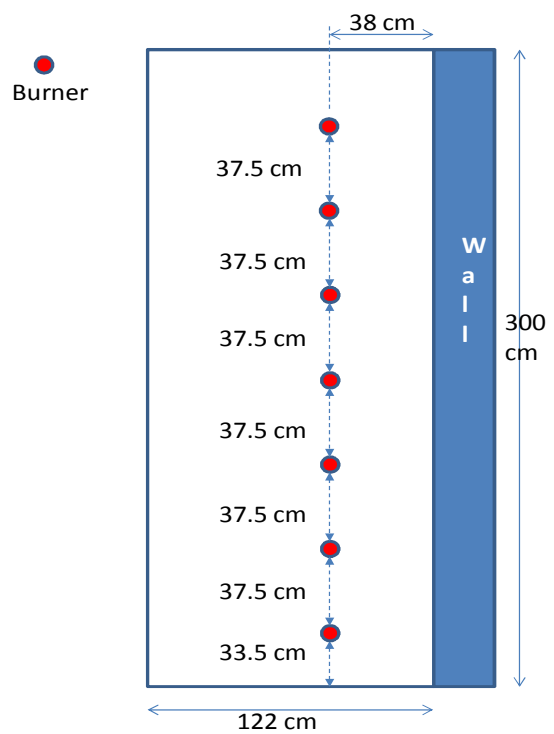

(b)

Fig. 3: Furnace employed for the fire test (a: picture of the test set-up; b: arrangement of the burners) [10].

Here samples prepared from 6 different mixes were tested, including four mixes of SGLC and two pure gypsum plasterboards, which were produced with an initial water/hemihydrate ratio of 0.65 and 1.00 , respectively. Three samples of each mix were tested. Samples were placed in the cavities of the wall of the furnace, as shown in Fig. 3a. The thicknesses of all the samples were precisely controlled to be the same $(20.0 \mathrm{~mm})$ in order to obtain representative results (the reason will be analyzed below). The temperature of the sample in the non-exposed side was monitored by 2 thermocouples. The thermocouples, which are copper disc (12 $\mathrm{mm}$ in diameter and $0.2 \mathrm{~mm}$ in thickness) type $\mathrm{K}$, were fixed using an adhesive tape and plaster to the samples. The exposed side of the sample was pre-cleaned and free of obstacles.

The fire test was performed following the ISO standard 834-1:1999 [11]. The average temperature of the furnace increases following

$$
T_{834-1}=345 \log _{10}(8 t+1)+20
$$

and is monitored by the interior thermocouples, where $\mathrm{T}_{834-1}$ is the average furnace temperature $\left({ }^{\circ} \mathrm{C}\right)$, and $\mathrm{t}$ is the time (min).

The temperature in the fire exposed side of the samples was not monitored since in the present study the heat transfer rate of the developed composites is the focus. The distances between the burner and the fire exposed side are the same for all the samples, as shown in Fig. 3b. Therefore, the heat is transferred from the burner to the fire exposed side with the same rate and the temperature of the fire exposed side is assumed to be the same for all samples. The duration of the fire test was 110 minutes. The temperature values were recorded continuously online, and the results are shown in Fig.4. 


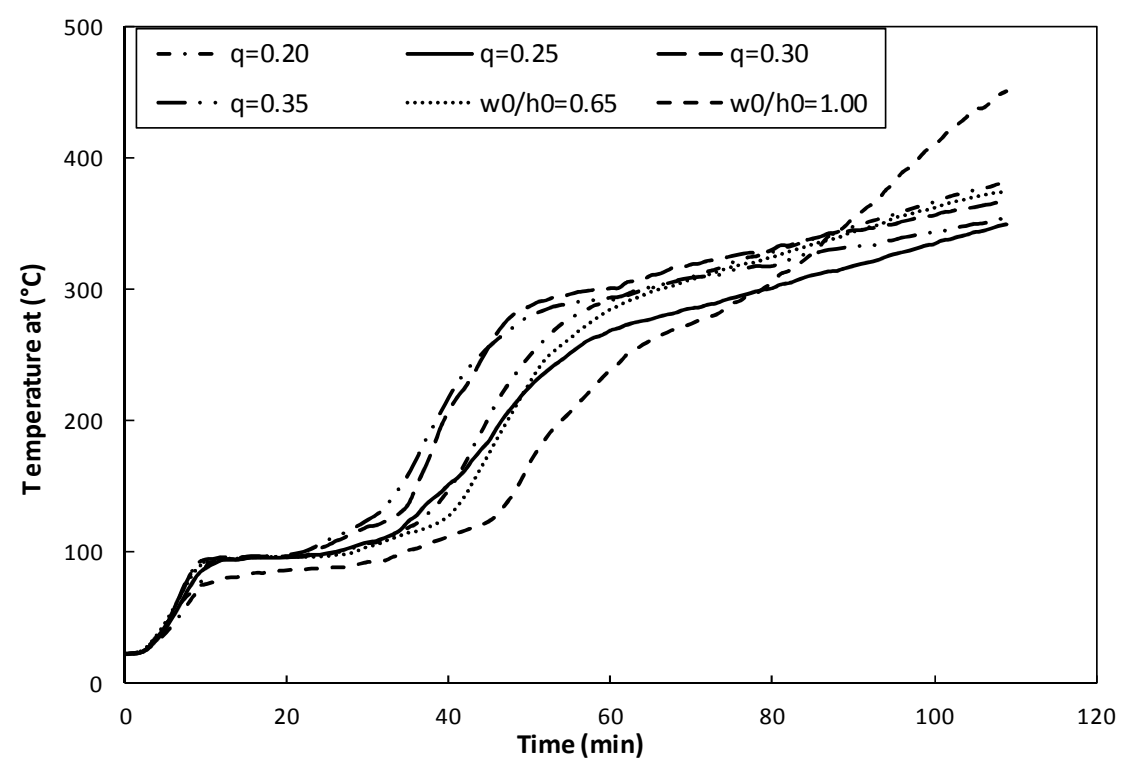

Fig. 4: Temperature increase at the non-exposed side of the samples during the fire test.

It can be clearly seen that the heat transfer is slower in the newly developed composite. In the case of a pure gypsum board, in Fig. 4 it can be seen that the heat transfer is becoming faster and faster, especially in the case of the gypsum board produced from a $\mathrm{w}_{0} / \mathrm{h}_{0}$ of 1.00 , the temperature increases sharply from 80 minutes on. This is in line with Mehaffey et al. [12], who reported a swift increase of the thermal conductivity when the temperature increases above $400{ }^{\circ} \mathrm{C}$. It is also evident that the sample (SGLC, $\mathrm{q}=0.25$ ) has the lowest temperature increase rate.

\section{Summary}

This article addresses the development of a sustainable and cost effective self-compacting gypsum-based lightweight composite. The modified Andreasen and Andersen grading line was used to design the composite with an optimal packing property. $\beta$-hemihydrate was used as binder and one type of lightweight material was used as aggregates in this composite. The following conclusions are drawn:

(1) A mix design methodology originally for concrete design is presented and applied to design the calcium sulfate-based lightweight composite. The mix design applies the geometric packing theory as the basic principle and the effect of the parameters in the mix design model is investigated;

(2) The thermo physical properties of the new composite are investigated and a $30 \%$ improvement compared to that of traditional gypsum plasterboard is reached with the same density;

(3) The fire behavior of the developed composite is studied by performing the real fire test following ISO standard 834-1. The lower temperature increase rate compared to the reference gypsum plasterboard confirms again not only the excellent property of teh newly designed composites but also the validity of the mix design method applied here.

\section{Acknowledgements}

The authors wish to express their appreciations to Prof. H. Hummel and Mrs. K. Engelhardt from Knauf Gips KG (Germany) for gypsum related material supply and Dr. Ch. Hampel for Sika Technology AG (Switzerland) from the superplasticizer supply. They furthermore express their gratitude to the following sponsors: Bouwdienst Rijkswaterstaat, Graniet-Import Benelux, Kijlstra Betonmortel, Struyk Verwo, Attero, Enci, Provincie Overijssel, Rijkswaterstaat Directie Zeeland, A\&G Maasvlakte, BTE, Alvon Bouwsystemen, V.d. Bosch Beton, Selor, Twee "R" Recycling, GMB, Schenk Concrete Consultancy, Geochem Research, Icopal, BN International, APP All Remove, Consensor, Eltomation, Knauf Gips KG, Hess ACC Systems, Kronos International, and Joma International AS (chronological order of joining). 


\section{Corresponding Author}

Dr. Q.L. Yu did his PhD research under the supervision of Prof. Dr. Ir. H.J.H. Brouwers in the Department of the Built Environment at Eindhoven University of Technology (the Netherlands) and received his $\mathrm{PhD}$ degree in May 2012. Currently he is a Post-Doctoral researcher at the same group. His research focuses on the design and development of sustainable building materials with multidisciplinary approaches applying materials science, civil engineering science and environmental engineering science, and his contact information is: email: q.yu@bwk.tue.nl, telephone: +31 (0)402472371.

\section{References}

[1] A.H.M. Andreasen, J. Andersen, Über die Beziehungen zwischen Kornabstufungen und Zwischenraum in Produkten aus losen Körnern (mit einigen Experimenten). Kolloid-Zeitschrift 50 (1930) 217-228 (In German).

[2] M. Hunger, H.J.H. Brouwers, Natural stone waste powders applied to SCC mix design. Restor. Build. Monum. 14 (2008) 131-140.

[3] G. Hüsken, H.J.H. Brouwers, A new mix design concept for earth-moist concrete: A theoretical and experimental study. Cem. Concr. Res. 38 (2008) 1246-1259.

[4] Q.L. Yu, H.J.H. Brouwers, Microstructure and mechanical properties of $\beta$-hemihydrate produced gypsum:An insight from its hydration proces. Const. Build. Mater. 25 (2011) 3149-3157.

[5] EN 13454-2. Binders, composite binders and factory made mixtures for floor screeds based on calcium sulfate - Part 2: Test methods, 2004.

[6] EFNARC. The European Guidelines for Self-Compacting Concrete Specification, Production and Use. EFNARC, 2005.

[7] A.C.J. de Korte, H.J.H. Brouwers, Calculation of thermal conductivity of gypsum plasterboards at ambient and elevated temperature. Fire Mater. 34 (2010) 55-75.

[8] P. Zehner, E.U. Schlunder, Thermal conductivity of granular materials at moderate temperatures. Chemie. Ingeieur. Technik. 14 (1970) 933-941.

[9] Q.L. Yu, H.J.H. Brouwers, Thermal properties and microstructure of gypsum board and its dehydration products:a theoretical and experimental investigation. Fire Mater. 36 (2012) 576-589.

[10] Q.L. Yu, Design of environmentally friednly calcium sulfate-based building materials: towards an improved indoor air qualiyt. PhD Thesis, Eindhoven University of Technology, Eindhoven, the Netherlands, 2012.

[11] International Organization for Standardization. Fire-resistance tests - Elements of building construction - Part 1: General requirements, ISO, Switzerland. Reference number: ISO 834-1:1999.

[12] J.R. Mehaffey, P. Cuerrier, and G. Carisse, A model for predicting heat transfer through gypsum-board/wood-stud walls exposed to fire. Fire Mater. 18 (1994) 297-305. 